we have applications to curvature, envelopes, singular points and tracing of curves.

The second part of the book contains the fundamental methods of the integral calculus, including a slight treatment of double and triple integrals and their applications to surfaces and volumes.

There is also a short chapter on differential equations, giving the methods of dealing with some of the simpler forms, and the concluding chapter contains applications to such subjects as moments of inertia and the deflection of beams.

Compared with recent English treatises on the calculus for engineering and physical students, the work before us appears slight and superficial in its technical applications. But as an elementary text-book on pure mathematics it has decided merit, and is evidently the production of an experienced teacher.

Album de Aves Amazonicas. Organisado pelo Dr.

Emilio A. Goeldi, Director do Museu Paraense. (Museu Paraense de Historia Natural e Ethnographia, 1900.)

THE illustrated supplement to Dr. Goeldi's "Aves do Brazil," of which the first part, consisting of twelve coloured plates designed by Señor Ernesto Lohse, has been issued, will when completed give a good general idea of the avifauna of those regions. The birds represented in the present fasciculus comprise the cormorants, grebes, gulls, terns, waders, plovers, herons, egrets, boatbill, storks, spoonbills, rails, geese, ducks, toucans and kingfishers, as well as those two curious forms, the hoactzin and the sun-bittern. In herons and their allies the country is very rich, and two plates illustrate ten species of toucan, both sexes in this, as well as in other cases, being figured when desirable. Several species are figured on most of the plates, and they number eighty in all. But one plate is entirely devoted to a beautiful illustration (produced from an instantaneous photograph taken in I900) of a breerling-place of the scarlet ibis. The crowd of graceful scarlet birds, backed by the rich, deep greenery of the western tropics, must afford a sight worth going to South America to see. There are pleasing bits of tropical scenery in the background of the plates, which form quite pretty pictures. The work has been printed at Zürich, and although the designs are on a rather small scale, and too much must not be expected of colour printing, the lllustrations of the birds strike us as being decidedly good, and we readily recognise at a glance several old South American acquaintances. The supplement will be most useful to any one travelling in the country who takes even a passing interest in natural history. The plates, like Jr. Goeldi's recently completed "Aves do Brazil," may be regarded as decidedly popular, and on that account will doubtless prove the more generally useful.

Qualitative Chemical Analysis, Organic and Inorganic.

By F. Mollwo Perkin, Ph.D. Pp. viii +266 . (London Longmans, Green and Co., I90I.)

THIs book begins with a gereral account of dry reactions and reactions in solution, attention being paid both to the manipulative and the theoretical aspects. Then follows the usual account of metals in groups with their tests, and afterwards come the acids. The remaining third of the book is devoted to what is called organic analysis, and here appears the most distinctive feature, namely, a list of tests for a great variety of organic substances-acids, alcohols, sugars, nitrogenous bases, glucosides and alkaloids. The intention of the author, as declared in the preface, has been " to write a book in which theory and practice are more or less dovetailed." It is difficult to find any realisation of this in the large section devoted to organic substances, but the treatment of the inorganic section is more in accordance with the stated object.

A. S.

\section{LEITERS TO THE EIITUR.}

[The Editor does not hold himself responsible for opinions ex. pressed by his correspondents. Neither can he undertake to return, or to conrespond with the writers of, reje: el inanuscripts intended for this or any olher part of NATUkE. No notice is taken of anonvmous communications.j

The Fire Walk Ceremony in Tahiti.

THE very remarkable description of the "Fire Walk" collected by Mr. Andrew Lang and others had aroused a curiosity in me to witness the original ceremony, which I have lately been able to gratify in a visit to Tahiti.

Among these notable accounts is one by Colonel Gudgeon, British Resident at Raratonga, describing the experiment by a man from Raiatea, and also a like account of the Fiji fire ceremony from Dr. T. M. Hocken, whose article is also quoted in Mr. Lang's paper on the "Fire Walk," in the Proceedengs of the Society for Psychical Research, February, I900. This extraordinary rite is also described by Mr. Fraser in the "Golden Bough," and by others.

I had heard that it was perfurmed in Tahiti in 1897 , and several persons there assured me of their having seen it, and one of them of his having walked through the fire himself under the guidance of the priest, Papa-Ita, who is said to be one of the last remnants of a certain order of the priesthood of Raiatea and who had also performed the rite at the island of Hawaii some time in the present year, of which circumstantial newspaper accounts were given, agreeing in all essential particulars with those in the accounts already cited. According to these, a pit was dug in which large stones were heated ret hot by a fire which had been burning many hours. The upper stones were pushed away just before the ceremony, so as to leave the lower stones to tread upon, and over these, "glowing red hot" (according to the newspaper accounts), Papa-Ita had walked with naked feet, exciting such enthusiasm that he was treated with great consideration by the whites, and by the natives as a God. I found it commonly believed in Tahiti that anyone who chose to walk after him, European or native, could do so in safety, secure in the magic which he exercises, if his instructions were exactly followed. Here in Tahiti, where he had "walked" four years before, it was generally believed among the natives, and even among the Europeans present who had seen the ceremony, that if anyone turned around to look back he immediately was burned, and I was told that all those who followed him through the fire were expected not to turn until they had reached the other side in safety, when he again entered the fire and led them back by the path by which he had come. I was further told by several who had tried it that the heat was not felt upon the feet, and that when shoes were worn the soles were not burned (for those who followed the priest's directions), but it was added by all that much heat was felt about the head.

Such absolutely extraordinary accounts of the performance had been given to me by respectable eyewitnesses and sharers in the trial, confirming those given in Hawaii, and, in the main, the cases cited by Mr. Lang, that I could not doubt that if all these were verified by my own observation, it would mean nothing less to me than a departure from the customary order of Nature, and something very well worth seeing indeed.

I was glad, therefore, to meet personally the priest, PapaIta. He is the finest looking native that I have seen; tall, dignified in bearing, with unusually intelligent features. I learned from him that he would perform the ceremony on Wednesday, July I7, the day before the sailing of our ship. I was ready to provide the cost of the fire, if he could not obtain it otherwise, but this proved to be unnecessary.

Papa-Ita himself spoke no English, and I conversed with him briefly through an interpreter. He said that he walked over the hot stones without danger by virtue of spells which he was able to utter and by the aid of a yoddess (or devil as my interpreter had it), who was formerly a native of the islands. The spells, he said, were something which he could teach another. I was told by others that there was a still older priest in the Island of Raiatea, whose disciple he was, although he had pupils of his own, and that he could "send his spirit" to Raiatea to secure the permission of his senior priest if necessary.

In answer to my inquiry as to what preparations he was going to make for the rite in the two or three days before it, he said he was going to pass them in prayer.

No. I66o, VOL. 64] 